Evans, D. G. \& Adams, Mary O. (1952). J. gen. Microbiol. 7, 169-174

\title{
The Inability of the Capsular Material of Haemophilus pertussis to produce Protective Antisera
}

\author{
By D. G. EVANS and MARY O. ADAMS \\ Department of Bacteriology, University of Manchester
}

\begin{abstract}
SUMMARY : Bacterial suspensions of capsulated Haemophilus pertussis, prepared from cultures freshly isolated from infected mice, or from Phase I strains maintained on Bordet Gengou medium, produced in rabbits antisera which contained specific agglutinating and complement-fixing antibodies and which protected mice against experimental pertussis infection. Organisms which had been washed three times with distilled water and freed from capsular material also produced similar antibodies. More than one antigen may be involved in the production of these antibodies.

On the other hand, bacilli-free preparations, containing the capsular material in a concentrated form, produced antisera with only low levels of agglutinating, complement-fixing and protective antibodies.

The experiments indicated that the antigens of $H$. pertussis which produced these antibodies are somatic rather than capsular.
\end{abstract}

It was previously shown (Evans, 1944) that pertussis antisera, from rabbits immunized with a heat-killed suspension or a detoxified extract of bacilli, protected mice against the infection induced by the intranasal instillation of Haemophilus pertussis. The protective action of the antisera was associated mainly with their specific agglutinating property, for antisera from which the agglutinins had been absorbed with heat-killed whole bacilli had a greatly reduced protective action. The ease with which absorption occurred and the completeness of the effect, suggested that the specific antigen involved was situated at the surface of the bacillus and was responsible for the production of protective antibody. It has been demonstrated that $H$. pertussis is surrounded by a capsular substance (Lawson, 1940) or slime layer (Klieneberger-Nobel, 1948). We have therefore investigated what part this substance might play in the production of protective antibody by comparing antisera prepared against whole capsulated bacilli, bacilli from which the capsular material had been removed, and capsular material in a concentrated form free from bacilli.

\section{EXPERIMENTAL}

\section{Staining of capsular material}

The method employed by Lawson (1940) was used. It involved the fixing of dry smears, made from cultures on Bordet Gengou medium (BG), by phosphomolybdic acid, washing with water, then with methanol and staining first with a concentrated solution and later with a dilute solution of Wright's stain in glycerol. The organisms stained red and appeared embedded in an amorphous capsular material which stained sky-blue. Sometimes, in thin smears, isolated organisms were seen surrounded by capsular material, the boundary of which was not well defined. Often, capsular material was seen in 
irregular masses completely detached from the bacilli. No capsular material was seen in smears prepared from organisms which had been treated with water before fixing. Ninety strains of $\boldsymbol{H}$. pertussis freshly isolated from whooping cough cases were examined, and each showed the presence of capsular material. Organisms cultured from mice which had been infected either intranasally (Burnet \& Timmins, 1937) or intracerebrally (Kendrick, Eldering, Dixon \& Misner, 1947) appeared similar on staining to those freshly isolated from cases of whooping cough.

Six strains which had been subcultured for several months on BG had capsular material, although it was decidedly less in quantity and not as deeply stained as with freshly isolated strains. Capsular material was also seen with two avirulent strains of $H$. pertussis, but the material was extremely diffuse, only faintly stained and did not appear in large masses.

From many observations it was considered that the capsular material was present in the most well-defined state and in the greatest quantity in those strains of $\boldsymbol{H}$. pertussis which had been freshly isolated either from cases of whooping-cough or from infected mice.

Capsular material could not be demonstrated by Lawson's method in ten strains of $\boldsymbol{H}$. parapertussis or in several strains of Bacterium coli and Staphylococcus aureus.

\section{Concentration of capsular material and preparation of suspensions}

In preparing concentrated capsular material, organisms from experimentally infected mice were cultured directly on BG; these cultures appeared to possess the greatest quantity of capsular material. It was difficult to obtain pure primary cultures from the lungs of mice infected intranasally, but when the intracerebral route was used, cultures from infected brains were invariably pure.

The following procedure was adopted. Twenty to thirty mice were infected intracerebrally with $H$. pertussis from a $24 \mathrm{hr}$. growth on BG suspended in Hartley broth. The infecting dose was such that the majority of the mice might be expected to die about the 10th day. On the 7 th day after inoculation, mice were killed; those dying before that time were discarded. The brains of the mice were removed aseptically, frozen at $-80^{\circ}$ and ground aseptically with carborondum. The resulting paste was suspended in broth and left to stand for $1 \mathrm{hr}$. to allow gross particles to settle. The supernatant fluid was then centrifuged at 10,000 r.p.m. for $30 \mathrm{~min}$. and the deposit suspended in a small volume of broth. The brains were ground in batches of five and with the extract from one batch 10 plates of BG medium were inoculated so as to obtain a confluent growth. A total of 50-60 plates were inoculated each time. After $48 \mathrm{hr}$. incubation the growth was scraped off with a loop and suspended in a small volume of sterile water. This suspension was designated MB/BG/U; organisms cultured from Mouse Brain on Bordet Gengou and Untreated. Part of this suspension was dried from the frozen state and preserved.

The rest of the suspension was diluted with sterile distilled water to give an opacity equal to no. 4 Brown's tube, transferred to a round-bottom flask and gently shaken for $1 \mathrm{hr}$. in a mechanical shaker. The suspension was then 
centrifuged at 10,000 r.p.m. for $30 \mathrm{~min}$. when the water-clear supernatant was removed and kept for further use. The deposit was resuspended in an equivalent volume of water, reshaken for $1 \mathrm{hr}$., then centrifuged and the supernatant discarded. The deposit was resuspended in water and shaken a third time, centrifuged again, the supernatant discarded and the thrice-washed organisms dried from the frozen state and preserved. The preparation was designated MB/BG/W3; organisms cultured from Mouse Brain on Bordet Gengou and Washed 3 times.

The water-clear supernatant from the first washing was filtered through a Gradacol membrane of $850 \mathrm{~m} \mu$, A.P.D. and the filtrate dried from the frozen state. The dry material was dissolved in $5 \mathrm{ml}$. of distilled water and distributed into ampoules in $1 \mathrm{ml}$. amounts and redried. Thus, the washings from the confluent growth of $\boldsymbol{H}$. pertussis on 50-60 plates were concentrated in 5 ampoules. This material was designated MB/BG/SF; Supernatant Fluid from washed organisms cultured from Mouse Brain on Bordet Gengou.

An adequate amount of the two preparations $\mathrm{MB} / \mathrm{BG} / \mathrm{U}$ and $\mathrm{MB} / \mathrm{BG} / \mathrm{W3}$ was obtained from two batches of infected mice, but in preparing $\mathrm{MB} / \mathrm{BG} / \mathrm{SF}$, many batches of mice were used on account of the low yield of material.

A fourth type of preparation was also made from strains which had been subcultured on BG every 2 or 3 days for 6 months. At the end of this period each strain, which was still agglutinated to titre by Phase I serum, was grown on BG for $48 \mathrm{hr}$. and the growth scraped off with a loop into distilled water and dried. This preparation was designated $\mathrm{BG} / \mathrm{L}$; organisms cultured on BG and Untreated.

The above experiments thus gave four different preparations:

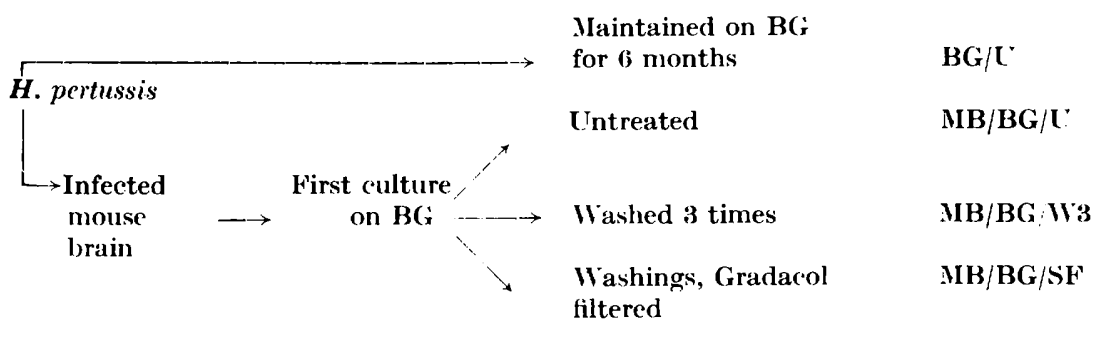

\section{Preparation of antisera.}

Antisera were prepared in rabbits against each of the above preparations. The various strains used are shown in Table 1 .

Suspensions of either washed or unwashed bacteria were prepared for inoculation by suspending the dried bacteria in saline to give an opacity equal to no. 6 Brown's tube. Rabbits were inoculated first subcutaneously and later intravenously with increasing doses over a period of approximately 3 months, the total inoculum amounting to 5-10 mg. dry bacteria.

Each rabbit receiving the $\mathrm{MB} / \mathrm{BG} / \mathrm{SF}$ preparations was given a longer series of injections and received subcutaneously each week for 4 months the dried material from one ampoule dissolved in saline. Thus each dose contained the concentrated washings from the growth on 10 plates of BG, the total amount 
inoculated being derived from 150-200 plates. Expressing the dose in terms of dry bacteria, each rabbit received the concentrated washings from 250-300 mg. of dry bacteria.

\section{Tests with sera from inoculated rabbits}

Each rabbit was bled at the end of its course of injections and the sera were tested for agglutinins, complement-fixing antibodies, antitoxin, and their ability to protect mice against pertussis infection.

Agglutination tests. These were made with a suspension of living $H$. pertussis from a $48 \mathrm{hr}$. growth on BG (opacity=no. 4 Brown's tube). Incubation of suspension and serum dilutions was for $2 \mathrm{hr}$. at $37^{\circ}$ and readings were finally made after the tubes had remained at room temperature overnight.

Complement-fixation tests. These were made with a thiomersalate-killed suspension of $H$. pertussis diluted to $1 / 5$ opacity of no. 4 Brown's tube, 3 M.H.D. of complement and $3 \%$ sheep cells sensitized with 5 M.I.D. of haemolysin. Fixation was for $1 \mathrm{hr}$. at $37^{\circ}$, and after adding the haemolytic system there was further incubation at $37^{\circ}$ for $1 \mathrm{hr}$., when the tests were read. Titres for both agglutination and complement-fixation tests are given in Table 1 as reciprocals.

Antitoxin tests. A saline suspension of living $I$. pertussis from a $48 \mathrm{hr}$. growth on BG was prepared to contain 20-40 minimal skin reacting doses of toxin in $\mathbf{0 . 2} \mathrm{ml}$. Falling two-fold dilutions of this suspension were mixed with an equal quantity of undiluted serum. The mixtures were left at room temperature for $1 \mathrm{hr}$. before they were injected intradermally in rabbits. By this method it was possible to detect whether $0.1 \mathrm{ml}$. of undiluted serum would neutralize the smallest dose of toxin which gave a skin reaction. Rabbits were observed for 1 week.

Protection tests. Mice were used in groups of $c .20$ and each mouse received intraperitoneally $0.5 \mathrm{ml}$. of serum diluted $1 / 2$. The mice were inoculated intranasally, 3-4 hr. after receiving serum, with approximately 10-100 minimal infecting doses of a suspension of $H$. pertussis from a $24 \mathrm{hr}$. culture. At least three tests were made at the same time, and always included one serum prepared against either washed or unwashed bacteria, one prepared against concentrated washings, and normal rabbit serum. Occasionally some of the mice died, but the majority remained alive and were killed 14 days after infection when the lungs were examined and cultured by smearing a cut surface over half a BG plate. With each animal, the degree of severity of the lung lesions and the extent of growth of $\boldsymbol{H}$. pertussis were recorded. Mice which failed to yield growth from the lung were considered to have been protected, and these mice usually did not have lung lesions.

\section{RESULTS}

The results of the in vitro serological tests are given in Table 1 . The agglutination titres of the sera prepared against the three kinds of bacterial suspension, $\mathrm{BG} / \mathrm{U}, \mathrm{MB} / \mathrm{BG} / \mathrm{U}$ and $\mathrm{MB} / \mathrm{BG} / \mathrm{W}$ 3, ranged from 3000 to 20,000. Significant deductions cannot be made from differences in titre of the three kinds of 
serum, as relatively few rabbits were immunized, but the two sera in the MB/BG/W 3 group each showed a lower titre than those in the BG/U and MB/BG/U groups. Sera prepared against MB/BG/SF, however, showed decidedly lower agglutination titres, from $<20$ to 320 . Similarly, the complement-fixing titres of the sera prepared against the bacterial suspensions were higher ( 16 to 128 ) than those prepared against the concentrated washings $(<2$ to 16$)$. Antitoxin was not detected in any of the sera.

\section{Table 1. In vivo and in vitro properties of pertussis antisera}

\begin{tabular}{|c|c|c|c|c|c|c|c|c|c|}
\hline $\begin{array}{l}\text { eparation } \\
\text { used for } \\
\text { Imunizing } \\
\text { rabbits }\end{array}$ & $\begin{array}{l}\text { Strains of } \\
H . \text { pertussis } \\
\text { from which } \\
\text { the prepara- } \\
\text { tion was made }\end{array}$ & $\begin{array}{l}\text { No. of } \\
\text { rabbit }\end{array}$ & $\begin{array}{l}\text { Agglutina- } \\
\text { tion titre }\end{array}$ & $\begin{array}{c}\text { Complement- } \\
\text { fixation } \\
\text { titre }\end{array}$ & $\begin{array}{l}\text { No. of mice } \\
\text { protected } / \text { no. } \\
\text { inoculated in } \\
\text { each test }\end{array}$ & $\begin{array}{l}\text { To } \\
\text { prope } \\
\text { prot }\end{array}$ & $\begin{array}{l}\text { otal } \\
\text { ortion } \\
\text { tected }\end{array}$ & $\begin{array}{l}\text { Total } \\
\text { protec }\end{array}$ & $\begin{array}{l}\% \text { od } \\
\text { ected }\end{array}$ \\
\hline $\mathbf{J} / \mathbf{U}$ & $\begin{array}{l}\text { A } 1 \\
\text { A } 18 \\
\text { A } 10\end{array}$ & $\begin{array}{l}1 \\
2 \\
3\end{array}$ & $\begin{array}{l}20,000 \\
10,000 \\
10,000\end{array}$ & $\begin{array}{r}128 \\
128 \\
16\end{array}$ & $\begin{array}{l}12 / 20,10 / 15,16 / 19 \\
18 / 20,20 / 20,15 / 19 \\
14 / 20\end{array}$ & $\left.\begin{array}{l}38 / 54 \\
53 / 59 \\
14 / 20\end{array}\right\}$ & $105 / 133$ & $\left.\begin{array}{l}70 \cdot 4 \\
89 \cdot 8 \\
70 \cdot 0\end{array}\right\}$ & $79 \cdot 0$ \\
\hline $\mathrm{B} / \mathbf{B G} / \mathbf{U}$ & $\begin{array}{c}\mathrm{A1} \\
18-323\end{array}$ & $\begin{array}{l}4 \\
5\end{array}$ & $\begin{array}{l}10,000 \\
20,000\end{array}$ & $\begin{array}{r}16 \\
128\end{array}$ & $\begin{array}{l}14 / 19 \\
14 / 18,15 / 20,18 / 20\end{array}$ & $\left.\begin{array}{l}14 / 19 \\
47 / 58\end{array}\right\}$ & $61 / 7 \gamma$ & $\left.\begin{array}{l}73 \cdot 7 \\
81 \cdot 0\end{array}\right\}$ & $79 \cdot 3$ \\
\hline B/BG/W3 & $\underset{18-323}{A 1}$ & $\begin{array}{l}6 \\
7\end{array}$ & $\begin{array}{l}3,000 \\
5,000\end{array}$ & $\begin{array}{l}64 \\
32\end{array}$ & $\begin{array}{l}17 / 19 \\
15 / 20\end{array}$ & $\left.\begin{array}{l}17 / 19 \\
15 / 20\end{array}\right\}$ & $32 / 39$ & $\left.\begin{array}{l}89 \cdot 4 \\
75 \cdot 0\end{array}\right\}$ & $82 \cdot 0$ \\
\hline $\mathbf{B} / \mathbf{B G} / \mathbf{S F}$ & $\begin{array}{c}\text { A1 } \\
\text { A1 } \\
\text { A1 } \\
\text { 18-323 } \\
18-323 \\
18-323\end{array}$ & $\begin{array}{r}8 \\
9 \\
10 \\
11 \\
12 \\
13\end{array}$ & $\begin{array}{r}320 \\
160 \\
20 \\
<20 \\
160 \\
<20\end{array}$ & $\begin{array}{r}8 \\
16 \\
16 \\
<2 \\
2 \\
2 \\
<2\end{array}$ & $\begin{array}{l}7 / 19,9 / 17,4 / 20 \\
7 / 20 \\
5 / 20 \\
1 / 20 \\
2 / 20 \\
5 / 20\end{array}$ & $\left.\begin{array}{r}20 / 56 \\
7 / 20 \\
5 / 20 \\
1 / 20 \\
0 / 18 \\
5 / 20\end{array}\right\}$ & $38 / 154$ & $\left.\begin{array}{r}35 \cdot 7 \\
35 \cdot 0 \\
25 \cdot 0 \\
5 \cdot 0 \\
0 \cdot 0 \\
\mathbf{2 5 \cdot 0}\end{array}\right\}$ & $24 \cdot 7$ \\
\hline on & $\begin{array}{l}- \\
- \\
- \\
-\end{array}$ & $\begin{array}{l}14 \\
15 \\
16 \\
17\end{array}$ & $\begin{array}{l}<\mathbf{2 0} \\
<20 \\
<\mathbf{2 0} \\
<\mathbf{2 0}\end{array}$ & $\begin{array}{l}<2 \\
<2 \\
<2 \\
<2\end{array}$ & $\begin{array}{l}4 / 19,0 / 15,3 / 20 \\
1 / 17,3 / 17,8 / 18 \\
0 / 20,0 / 20,0 / 16 \\
3 / 20\end{array}$ & $\left.\begin{array}{r}7 / 54 \\
12 / 52 \\
0 / 56 \\
3 / 20\end{array}\right\}$ & $22 / 182$ & $\left.\begin{array}{r}13 \cdot 0 \\
23 \cdot 1 \\
0 \cdot 0 \\
15 \cdot 0\end{array}\right\}$ & $12 \cdot 1$ \\
\hline
\end{tabular}

$\mathrm{BG} / \mathrm{U}=$ Organisms grown on BG and suspended in saline.

$\mathrm{MB} / \mathrm{BG} / \mathrm{U}=$ Organisms from infected mouse brain, grown on $\mathrm{BG}$ and suspended in saline. MB/BG/W 3 = Organisms prepared as with $\mathrm{MB} / \mathrm{BG} / \mathrm{C}$ but washed three times with water. $\mathbf{M B} / \mathbf{B G} / \mathrm{SF}=$ Concentrated washings from organisms prepared as with $\mathrm{MB} / \mathrm{BG} / \mathrm{U}$.

The results of the protection experiments are also given in Table 1 and indicate the proportion of mice protected against infection. Table 2 gives the degree of infection in the unprotected animals as indicated by lung lesions and growth of $\boldsymbol{H}$. pertussis. Antisera prepared against the bacterial suspensions, either washed or unwashed, either from mouse brain cultures or from cultures which had not been passaged through mice, gave protection. The percentage of mice protected with each of the three types of antisera were similar, 79 , $79 \cdot 3$ and 82 . On the other hand, antisera prepared against the concentrated washings of the bacilli gave decidedly less protection, the average percentage of mice protected by the six sera being $24 \cdot 7$. Two of these sera gave negligible or no protection, two others were no better than one of the normal sera and the two which gave the best protection were greatly inferior to the least potent serum made against bacterial suspensions. The degree of severity of the lung lesions and the extent of the growth of $\boldsymbol{H}$. pertussis from lung cultures also 
indicated the low protective action of the $\mathrm{MB} / \mathrm{BG} / \mathrm{SF}$ sera compared with that of sera prepared against the bacterial suspensions.

Table 2. The protective properties of pertussis antisera shown by $(a)$ severity of lung lesions and $(b)$ extent of growth of $\mathrm{H}$. pertussis from lung

\begin{tabular}{|c|c|c|c|c|c|c|c|c|c|}
\hline \multirow[b]{2}{*}{ Serum } & \multirow{2}{*}{$\begin{array}{l}\text { Total no. } \\
\text { of mice } \\
\text { treated }\end{array}$} & \multicolumn{4}{|c|}{$\begin{array}{l}\text { No. and (\%) of mice } \\
\text { showing varying degrees } \\
\text { of severity of lung lesions }\end{array}$} & \multicolumn{4}{|c|}{$\begin{array}{l}\text { No. and }(\%) \text { of mice } \\
\text { giving varying degrees of } \\
\text { growth of } H \text {. pertussis }\end{array}$} \\
\hline & & $* * *$ & ** & * & () & $+t+$ & $+t$ & + & - \\
\hline $\mathbf{B G} / \mathbf{C}$ & 133 & $\begin{array}{c}7 \\
(5 \cdot 2)\end{array}$ & $\begin{array}{c}5 \\
(3 \cdot 8)\end{array}$ & $\begin{array}{c}7 \\
(12 \cdot 8)\end{array}$ & $\begin{array}{c}104 \\
(78 \cdot 2)\end{array}$ & $\begin{array}{c}3 \\
(2 \cdot 3)\end{array}$ & $\begin{array}{c}13 \\
(9 \cdot 8)\end{array}$ & $\begin{array}{c}12 \\
(9 \cdot 0)\end{array}$ & $\begin{array}{l}105 \\
(78 \cdot 9)\end{array}$ \\
\hline $\mathrm{MB} / \mathrm{BG} / \mathrm{U}$ & 77 & $\begin{array}{c}0 \\
(0)\end{array}$ & $\begin{array}{c}1 \\
(1 \cdot 3)\end{array}$ & $\begin{array}{c}15 \\
(19 \cdot 5)\end{array}$ & $\begin{array}{c}61 \\
(79 \cdot 2)\end{array}$ & $\begin{array}{c}1 \\
(\mathbf{1} \cdot \mathbf{3})\end{array}$ & $\begin{array}{c}7 \\
(9 \cdot 1)\end{array}$ & $\begin{array}{c}8 \\
(10 \cdot 4)\end{array}$ & $\begin{array}{c}61 \\
(79 \cdot 2)\end{array}$ \\
\hline $\mathrm{MB} / \mathrm{BG} / \mathrm{W} 3$ & 39 & $\begin{array}{c}2 \\
(5 \cdot 1)\end{array}$ & $\begin{array}{c}4 \\
(10 \cdot 2)\end{array}$ & $\begin{array}{c}1 \\
(2 \cdot 6)\end{array}$ & $\begin{array}{c}32 \\
(82 \cdot 1)\end{array}$ & $\begin{array}{c}\mathbf{0} \\
(0)\end{array}$ & $\begin{array}{c}2 \\
(5 \cdot 1)\end{array}$ & $\begin{array}{c}5 \\
(12 \cdot 8)\end{array}$ & $\begin{array}{c}32 \\
(82 \cdot 1)\end{array}$ \\
\hline $\mathbf{B M} / \mathbf{B G} / \mathbf{S F}$ & 154 & $\begin{array}{c}91 \\
(59 \cdot 1)\end{array}$ & $\begin{array}{c}17 \\
(11 \cdot 0)\end{array}$ & $\begin{array}{c}12 \\
(7 \cdot 8)\end{array}$ & $\begin{array}{c}34 \\
(22 \cdot 1)\end{array}$ & $\begin{array}{c}55 \\
(\mathbf{3 5} \cdot 7)\end{array}$ & $\begin{array}{c}36 \\
(23 \cdot 4)\end{array}$ & $\begin{array}{c}25 \\
(16 \cdot 2)\end{array}$ & $\begin{array}{c}38 \\
(\mathbf{2 4} \cdot 7)\end{array}$ \\
\hline None & 182 & $\begin{array}{c}108 \\
(59 \cdot 3)\end{array}$ & $\begin{array}{c}32 \\
(17 \cdot 6)\end{array}$ & $\begin{array}{c}23 \\
(12 \cdot 6)\end{array}$ & $\begin{array}{c}19 \\
(10 \cdot 4)\end{array}$ & $\begin{array}{c}92 \\
(50 \cdot 5)\end{array}$ & $\begin{array}{c}47 \\
(25 \cdot 8)\end{array}$ & $\begin{array}{c}21 \\
(11 \cdot 5)\end{array}$ & $\begin{array}{c}22 \\
(12 \cdot 1)\end{array}$ \\
\hline
\end{tabular}

Macroscopic lung lesions: 0 , normal lung; *, **, ***, increasing degrees of severity of lung congestion. Extent of growth of $H$. pertussis from lung: - , no colonies;,$+<100$ colonies; ++ , numerous colonies; +++ , confluent growth.

\section{CONCLUSIONS}

It is evident that the antigens of $H$. pertussis which produce agglutinating, complement-fixing and protective antibodies are somatic rather than capsular. It is probable that the antibodies detected in the antisera against the washings from $H$. pertussis were a result of the small amount of somatic antigen removed from the bacilli during washing rather than to the capsule itself.

\section{REFERENCES}

Burnet, F. M. \& Timmins, C. (1937). Experimental infection with Haemophilus pertussis in the mouse by intranasal inoculation. Brit. J. exp. Path. 18, 83.

Evans, D. G. (1944). The protective properties of pertussis antisera in experimental infection. J. Path. Bact. 56, 49.

Kendrick, P. L., Eldering, G., Dixon, M. K. \& Misner, J. (1947). Mouse protection tests in the study of pertussis vaccines. Amer. J. publ. Hlth, 37, 803.

Klieneberger-Nobel, E. (1948). Capsules and mucoid envelopes of bacteria. J. Hyg., Camb. 46, 345.

Lawson, G. M. (1940). Modified technique for staining capsules of Haemophilus pertussis. J. Lab. clin. Med. 25, 435.

(Received 27 February 1952) 